\title{
Pseudodelphis limnicola sp. n. (Dracunculoidea: Guyanemidae) from the heart of Percichthys trucha (Perciformes: Percichthyidae) in Patagonian Andean lakes (Argentina)
}

\author{
Norma Brugni and Gustavo Viozzi
}

Laboratorio de Parasitología, Centro Regional Universitario Bariloche, Universidad Nacional del Comahue, Quintral 1250, (8400) San Carlos de Bariloche, Argentina

Key words: Dracunculoidea, Guyanemidae, Pseudodelphis limnicola, Percichthys trucha, Patagonia

\begin{abstract}
During a survey of parasites of Percichthys trucha (Cuvier et Valenciennes) (Perciformes: Percichthyidae) in northwestern Patagonian lakes, a new dracunculoid of the family Guyanemidae was found parasitizing as adults the heart of the fish. This species belongs to the genus Pseudodelphis Adamson et Roth, 1990 by having deirids, glandular multinucleate oesophagus and anterior branch of the uterus, and by lacking caudal alae and a gubernaculum. Pseudodelphis limnicola sp. n. differs from Pseudodelphis oligocotti Adamson et Roth, 1990 by the number and distribution of the cephalic papillae, a muscular oesophagus submerged into the glandular portion and by lacking a peribuccal ring. This is the first record of a guyanemid inhabiting the heart of a Neotropical perciform fish.
\end{abstract}

Nematodes of the superfamily Dracunculoidea Stiles, 1907 represent a large, diverse group of parasites with a worldwide distribution. Moravec (2004) recognized nine families, of which only Philometridae Baylis et Daubney, 1926, Daniconematidae Moravec et Køie, 1987 and Guyanemidae Petter, 1975 contain species parasitic as adults in Neotropical freshwater fishes (Moravec 1998). The classification within this parasite group is difficult and the males of the majority of species have not yet been described.

During a survey of parasites of Percichthys trucha (Cuvier et Valenciennes) in north-western Patagonia, adults of a new guyanemid nematode were found in the heart of this fish. Its morphological features and the site of infection fit with those of the genus Pseudodelphis Adamson et Roth, 1990. The type and the only species of the latter, Pseudodelphis oligocotti Adamson et Roth, 1990, was described from males and non-larvigerous females found in the abdominal cavity of Oligocottus maculosus Girard (Scorpaeniformes) from the western coast of Canada (Adamson and Roth 1990). Bennett and Adamson (2004) found 9 of 24 fish species infected with $P$. oligocotti (including $O$. maculosus), of which only Apodichthys flavidus Girard (Perciformes) harboured larvigerous females in the heart; therefore, considering also the prevalence and intensity of infection, this fish species was considered the principle definitive host.

The dracunculoid species with gravid females occuring in the lumen of the host's circulatory system are Lockenloia sanguinis Adamson et Caira, 1991, some species of Philometra Costa, 1845, Syngnathinema californiense Moravec, Spangenberg et Frasca, 2001 and Pseudodelphis oligocotti (see Adamson and Roth 1990,
Adamson and Caira 1991, Moravec 1994, 1998, Moravec et al. 2001, Bennett and Adamson 2004). Although Hystodites microocellatus Aragort, Alvarez, Iglesias, Leiro et Sanmartín, 2002 can be also found in the circulatory system, it is a tissue parasite (Aragort et al. 2002). In Patagonia, there are no records of dracunculoids parasitizing circulatory system; the only record of a dracunculoid from the fish is Philonema percichthydis Moravec, Urawa et Coria, 1997 described from larvigerous females found in the abdominal cavity of $P$. trucha in Lake Aluminé (Moravec et al. 1997).

\section{MATERIALS AND METHODS}

Two hundred and twenty-five specimens of $P$. trucha were sampled between 1995 and 1997 from Lake Escondido $\left(41^{\circ} 05^{\prime} \mathrm{S}, 71^{\circ} 35^{\prime} \mathrm{W}\right)$, a shallow water body (8.3 m depth) located in the Nahuel Huapí National Park. Additionally, 652 specimens of Galaxias maculatus (Jenyns) and 8 specimens of Oncorhynchus mykiss (Walbaum) were captured. Samples of $P$. trucha were taken also in other lakes located between $39^{\circ} 25^{\prime} \mathrm{S}$ and $42^{\circ} 08^{\prime} \mathrm{S}$, and only the hearts of these fish were examined (Table 1). The fish were captured with gill nets or traps, immediately transported to the laboratory and their organs examined under a stereoscopic microscope. Some nematodes were fixed in 5\% formalin, cleared using Aman's lactophenol and studied with the light microscope. Others were dehydrated through graded ethanol, dried in a critical point drier, coated with gold and examined with a JEOL JSM 100 scanning electron microscope. Illustrations were prepared with the aid of a camera lucida. Some measurements were obtained by using a calibrated curvimeter on camera lucida drawings. All measurements are given in $\mu \mathrm{m}$ unless otherwise stated, with the range followed by mean in parentheses. 
Table 1. Geographical location of the lakes, number of fish sampled, prevalence, and mean intensity of gravid females of Pseudodelphis limnicola sp. n. from the heart of Percichthys trucha.

\begin{tabular}{|l|c|c|c|c|}
\hline \multicolumn{1}{|c|}{ Lake } & Location & $\begin{array}{c}\text { No. of fish } \\
\text { sampled }\end{array}$ & $\begin{array}{c}\text { Prevalence } \\
(\%)\end{array}$ & $\begin{array}{c}\text { Mean } \\
\text { intensity }\end{array}$ \\
\hline Quillén & $39^{\circ} 25^{\prime} \mathrm{S}, 71^{\circ} 20^{\prime} \mathrm{W}$ & 8 & 12.5 & 1 \\
Villarino & $40^{\circ} 28^{\prime} \mathrm{S}, 71^{\circ} 35^{\prime} \mathrm{W}$ & 14 & 14 & 1 \\
Falkner & $40^{\circ} 29^{\prime} \mathrm{S}, 71^{\circ} 29^{\prime} \mathrm{W}$ & 6 & 33 & 2.5 \\
Espejo & $40^{\circ} 41^{\prime} \mathrm{S}, 71^{\circ} 40^{\prime} \mathrm{W}$ & 25 & 0 & 0 \\
Correntoso & $40^{\circ} 44^{\prime} \mathrm{S}, 71^{\circ} 39^{\prime} \mathrm{W}$ & 22 & 0 & 0 \\
Moreno & $41^{\circ} 03^{\prime} \mathrm{S}, 71^{\circ} 31^{\prime} \mathrm{W}$ & 140 & 0 & 0 \\
Puelo & $42^{\circ} 08^{\prime} \mathrm{S}, 71^{\circ} 38^{\prime} \mathrm{W}$ & 11 & 36 & 1.5 \\
\hline
\end{tabular}

\section{RESULTS}

In Lake Escondido, only P. trucha harboured guyanemid nematodes. A total of 35 males and 225 females were obtained: 41 larvae from intestine (15 males, 26 females), 30 (L4/sub-adults) from abdominal cavity (14 males, 16 females) and 189 (sub-adults/adults) from the heart (6 males, 183 females). Gravid females (ovigerous and larvigerous) were recovered only from the heart.

\section{Pseudodelphis limnicola sp. n.}

Figs. 1, 2

Description: Body filiform. Head end rounded, caudal end conical. Oral aperture oval, without peribuccal ring, surrounded by 12 cephalic papillae arranged in 2 circles. Buccal capsule absent. Oesophagus divided into short anterior muscular and long posterior glandular portions. Anterior end of oesophagus inflated. Posterior end of muscular oesophagus submerged into glandular one. Nerve ring encircling muscular oesophagus. Excretory pore situated below level of nerve ring. Deirids small, situated slightly posterior to nerve ring. Males considerably smaller than females.

Male ( $\mathrm{n}=20$ specimens): Length of body $18.1-24.8$ (20.7) mm, maximum width 137-190 (171). Length of muscular oesophagus 545-682 (605), width 38-55 (46), length of glandular oesophagus 1,545-2,091 (1,739), maximum width 94-134 (109); their length ratio 1: 2.42.8 (2.6). Distance of nerve ring 269-384 (306) from anterior extremity. Deirids 420-432 (426) and excretory pore 423-518 (480) from anterior extremity. Anterior end of testis 144-1,030 (423) from posterior end of glandular oesophagus. Two spicules equal, slightly curved, well sclerotized, 43-50 (46) long. Gubernaculum absent. Tail pointed, elongate, 273-364 (328) long, with elevated cloaca. Caudal papillae: 2-4 (3) pairs preanal, 1-2 (1) adanal and 4-7 (5) postanal. Postanal papillae in two groups, generally with 3 anterior pairs and 1 posterior pair. Caudal alae absent.

Female $(\mathrm{n}=1$ ovigerous +19 larvigerous specimens): Length of body 26.1-121.7 (94.1) mm, maximum width 432-893 (681). Length of muscular oesophagus 727-1,091 (887), width 48-67 (58), length of glandular oesophagus 2,130-3,871 (3,584), maximum width 125-240 (189); their length ratio 1: 3.4-3.6 (3.5).
Nerve ring 291-509 (440), deirids 396-532 (464), and excretory pore 509-778 (671) from anterior extremity. Anterior end of uterus located dorsally, extending up to anterior part of glandular oesophagus, 1,171-2,556 $(1,584)$ from anterior extremity. Vulva non-elevated $3,181-8,804(6,397)$ from anterior extremity. Vagina directed posteriorly, 176-249 (222) long. Tail pointed, elongate, 528-1,000 (717) long, with slightly elevated anus. Ovary 1,046-2,903 $(2,122)$ from posterior extremity. Larvae 636-773 (711) long and 28-36 (32) wide.

$\mathrm{T}$ y p e hos $\mathrm{t}$ : Percichthys trucha (Cuvier et Valenciennes) (Perciformes, Percichthyidae).

$\mathrm{S}$ it e s of i n f e cti o $\mathrm{n}$ : Sinus venosus and atrium (adult males and gravid females), intestine (larvae), and abdominal cavity (larvae and sub-adults).

Type 1 o c a lity: Lake Escondido $\left(41^{\circ} 05^{\prime} \mathrm{S}, 71^{\circ} 35^{\prime} \mathrm{W}\right)$.

Other loc alities: See Table 1.

Preva 1 e n c e : $50 \%$ (Lake Escondido).

Maximum intensity: 12 (Lake Escondido).

S p e c i m e n s d e p os i t e d : Holotype male No. 429/1 and allotype female No. 429/2, paratypes Nos. 429/3-6 (4 females) and 429/7-10 (4 males) deposited in the Colección Nacional de Parasitología del Museo Argentino de Ciencias Naturales Bernardino Rivadavia, Buenos Aires, Argentina; paratypes No. 5519 (4 females and 4 males) deposited in the Colección Helmintológica del Museo de La Plata, Museo de La Plata, Argentina; paratypes Nos. 201/1-10 (10 females) and 201/11-20 (10 males) deposited in the Colección Parasitológica de la Universidad Nacional del Comahue, (Bariloche, Argentina) and paratypes No. N833 ( 1 male and 1 female) deposited in the Helminthological Collection, Institute of Parasitology, Academy of Sciences of the Czech Republic, České Budějovice.

E t y molog y: The species epithet refers to the freshwater habitat of the host.

\section{DISCUSSION}

At present, the family Guyanemidae includes five genera: Guyanema Petter, 1974 with species parasitic in the body cavity of erythrinids, loricariids and characids (Moravec 1998); Pseudodelphis represented by a species whose gravid females occur in the circulatory system of pholid fishes (Bennett and Adamson 2004); Travassosnema Costa, Moreira et Oliveira, 1991 


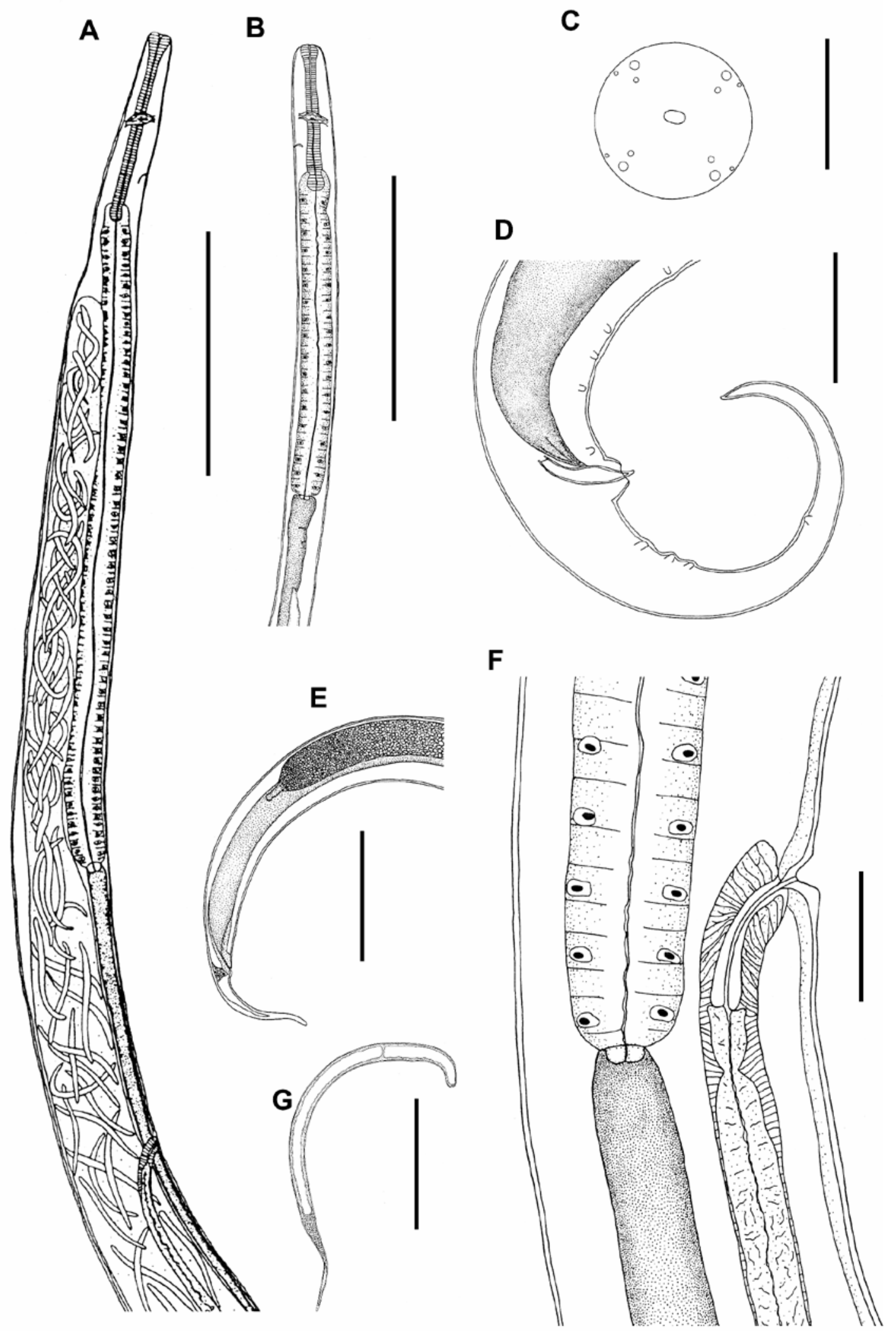

Fig. 1. Pseudodelphis limnicola sp. $\mathrm{n}$. $\mathbf{A}$ - anterior part of body of gravid female; $\mathbf{B}$ - anterior part of male, with anterior end of testis; $\mathbf{C}$ - cephalic end of female, apical view; $\mathbf{D}$ - posterior part of male; $\mathbf{E}$ - posterior part of female with ovary; $\mathbf{F}$ - region of vulva, lateral view; $\mathbf{G}$ - larva from uterus. Scale bars: A, B $=1 \mathrm{~mm} ; \mathrm{C}, \mathrm{D}=50 \mu \mathrm{m} ; \mathrm{E}, \mathrm{F}, \mathrm{G}=200 \mu \mathrm{m}$. 

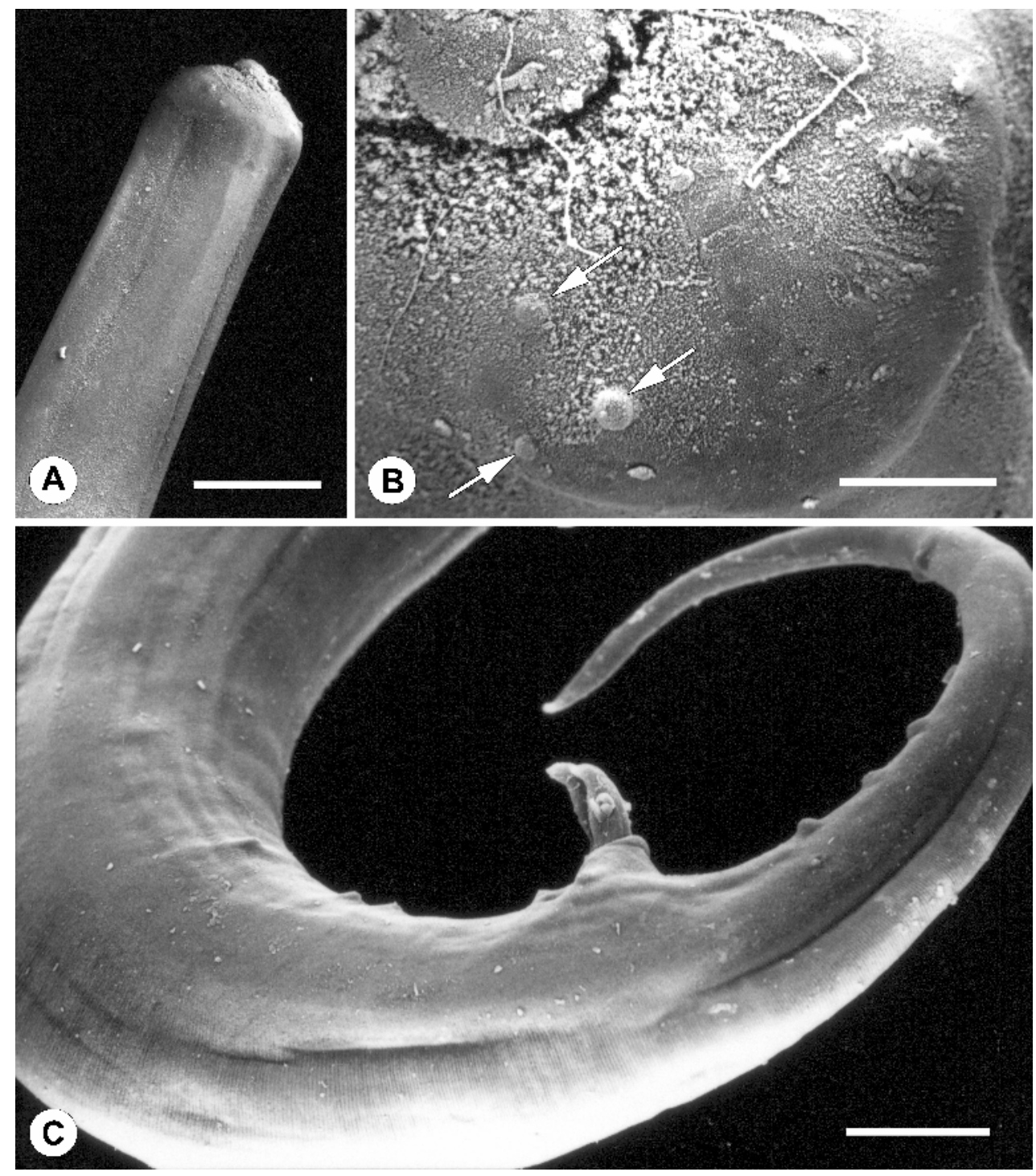

Fig. 2. Pseudodelphis limnicola sp. n., scanning electron micrographs. A - anterior part of body of male; $\mathbf{B}$ - apical view of male; see detail of cephalic papillae (arrows); $\mathbf{C}$ - caudal end of male, with protruded spicules and papillae. Scale bars: $\mathrm{A}=100$ $\mu \mathrm{m} ; \mathrm{B}=20 \mu \mathrm{m} ; \mathrm{C}=5 \mu \mathrm{m}$.

containing species from the orbital tissues and body cavity of characid fishes (Costa et al. 1991); the monotypic Histodytes from gills and viscera of rajid fishes (Aragort et al. 2002); and Moravecia Ribu et Lester, 2004 , the only species of which occurs in the gill filaments of diodontid fishes (Ribu and Lester 2004). The new species fits in Pseudodelphis by having a glandular multinucleate oesophagus, deirids, anterior branch of the uterus, and by lacking a transversely striated cuticle, dorsal appendix extending posteriorly from the glandular oesophagus, caudal alae, gubernaculum, and elevated vulva. Pseudodelphis limnicola differs from $P$. oligocotti in having a muscular oesophagus submerged into the glandular portion, in the number and distribution of the cephalic papillae and in the absence of a peribuccal ring. Although the hosts of both species are perciform, $P$. limnicola parasitizes Patagonian percichthyids, whereas the most suitable host of $P$. oligocotti is a coastal Pacific pholid.

Bennett and Adamson (2004) reported the presence of $P$. oligocotti in a wide range of marine fishes of Canada, but the parasites were able to reproduce only in a perciform fish. In Lake Escondido, P. trucha was the only host of $P$. limnicola, although the native $G$. maculatus and the introduced $O$. mykiss also inhabit the lake.

Bennett and Adamson (2004) assumed that Pseudodelphis oligocotti is transmitted to fish by ingestion of an infected copepod, the worms migrate from intestine to the abdominal cavity and reach the heart where gravid females release larvae, which exit the host via the gills. Judging from the localisation of the different larval stages of $P$. limnicola, a similar pattern of migration 
can be inferred: the larvae are probably acquired by ingestion of an intermediate host, then they migrate through the body cavity to the sinus venosus and atrium of the heart, where females are fecundated and release first-stage larvae. Although the way in which the larvae reach the external environment remains unknown, it could be also through the gills.

Moravec et al. (1997) described the philometrid Philonema percichthydis from the abdominal cavity of
P. trucha in Lake Aluminé. Since only two females of this species were found, it would be useful to complete the study based on a new material from the type locality in order to elucidate the relationship between these two dracunculoids parasitizing Patagonian percichthyids.

Acknowledgements. We thank Dr. František Moravec for his critical comments on the manuscript. Financial support was provided by Universidad Nacional del Comahue Grant B-115 and CONICET PIP - 02752 .

\section{REFERENCES}

ADAMSON M.L., CAIRA J.N. 1991: Lockenloia sanguinis n. gen., n. sp. (Nematoda: Dracunculoidea) from the heart of a nurse shark, Ginglymostoma cirratum, in Florida. J. Parasitol. 77: 663-665.

ADAMSON M.L., ROTH M. 1990: Prevalence and intensity of Pseudodelphis oligocotti n. gen., n. sp. (Dracunculoidea; Guyanemidae) in the tidepool sculpin, Oligocottus maculosus (Scorpaeniformes; Cottidae). J. Parasitol. 76: 509-514.

ARAGORT W., ALVAREZ F., IGLESIAS R., LEIRO J., SANMARTÍN M.L. 2002: Histodytes microocellatus gen. et sp. nov. (Dracunculoidea: Guyanemidae), a parasite of Raja microocellata on the European Atlantic coast (northwestern Spain). Parasitol. Res. 88: 932-940.

BENNETT S.N., ADAMSON M.L. 2004: Prevalence, intensity, and differential development of Pseudodelphis oligocotti (Nematoda: Dracunculoidea) in sympatric fish hosts of the northeastern Pacific coast. J. Parasitol. 90: 678-684.

COSTA H.M.A., MOREIRA N.I.B., OLIVEIRA C.L. 1991: Travassosnema gen. $\mathrm{n}$. with the description of $T$. travassosi sp. n. (Dracunculoidea, Guyanemidae) parasite of Acestrorhynchus lacustris Reinhardt, 1874 (Characidae) from Três Marias Reservoir, MG, Brazil. Mem. Inst. Oswaldo Cruz 86: 437-439.

MORAVEC F. 1994: Parasitic Nematodes of Freshwater Fishes of Europe. Academia and Kluwer Academic Publishers, Prague and Dordrecht, Boston, London, $473 \mathrm{pp}$.

MORAVEC F. 1998: Nematodes of Freshwater Fishes of the Neotropical Region. Academia, Prague, 464 pp.

MORAVEC F. 2004: Some aspects of the taxonomy and biology of dracunculoid nematodes parasitic in fishes: a review. Folia Parasitol. 51: 1-13.

MORAVEC F., SPANGENBERG J.B., FRASCA S. Jr. 2001: Syngnathinema californiense n. gen., n. sp. (Nematoda: Dracunculoidea) from the circulatory system of the bay pipefish Syngnathus leptorhynchus in California. J. Parasitol. 87: 1429-1432.

MORAVEC F., URAWA S., CORIA C.O. 1997: Philonema percichthydis sp. n. (Nematoda: Philometridae) from the Patagonian smallmouth perch Percichthys trucha (Pisces) from Argentina. Helminthologia 34: 215-219.

RIBU D.L., LESTER R.J.G. 2004: Moravecia australiensis n. g., n. sp. (Dracunculoidea: Guyanemidae) from the gills of the green porcupine fish Tragulichthys jaculiferus $(\mathrm{Cu}-$ vier) in Australia. Syst. Parasitol. 57: 59-65.

Accepted 4 October 2005 